\title{
Study on energy-saving diagnosis evaluation mode of boiler system
}

\author{
Xiao Xu ${ }^{1,2, *}$, Rujie Liu ${ }^{1,2}$, Zheng Liu ${ }^{1,2}$ \\ ${ }^{1}$ NARI Group Corporation/State Grid Electric Power Research Institute, Nanjing, China; \\ ${ }^{2}$ State Grid Electric Power Research Institute Wuhan Efficiency Evaluation Company limited, Wuhan, China
}

\begin{abstract}
Efficiency and energy consumption of boiler systems are affected by many factors. Firstly, the idea of boiler system being divided into different level subsystems is put forward, and the evaluation model of boiler efficiency and energy consumption is established. Secondly, analytic hierarchy process (AHP) is used to judge the matrix of the evaluation model's influence weight on the overall target. The model can be used to guide the energy saving diagnosis and analysis of boiler system. Compared with the key factors, the energy saving potential is analyzed from the aspects of economy, energy saving and environmental protection.
\end{abstract}

\section{Introduction}

Industrial boiler is a major energy conversion equipment, in addition to providing steam power for industrial production, but also to meet people's basic needs of life. In the work of energy saving and emission reduction, industrial boilers with high energy consumption should be taken as the focus to diagnose their energy efficiency level, so as to tap the potential of energy saving and achieve better energy saving effect ${ }^{[1-4]}$.

\section{Boiler system diagnosis method and index system}

\subsection{Diagnostic methods for boiler system energy efficiency}

The boiler system can be decomposed into different levels of subsystems and equipment units[5]. The boiler system and these subsystems and equipment units are equal to individual objects. The state of an object is described by the parameters of object. Under normal circumstances, the object has its inherent function. That is, the parameters of the object must meet certain constraint relations, which are determined by the relevant physical laws. To describe a system, the object must include parameters that reflect the state of the system and constraints on the relationships between those parameters. Once the constraint relationship between parameters is destroyed, the parameters or the relationship between parameters will show different characteristics for different abnormal reactions [6-7].

The boiler system is classified at all levels as follows:

Level 1: Treat the whole boiler as one object. Under normal operating conditions, the boiler system should output a certain quality of excess and reheated steam and flue gas given a certain load, coal type, atmospheric

\footnotetext{
* Corresponding author: xuxiaosgcc@foxmail.com
}

environment and other system inputs. At the same time, some key parameters of the boiler should be tested, such as drum water level, negative pressure of the furnace, which must meet certain requirements in normal operation.

To be specific, the input parameters of the boiler are load, coal type, atmospheric environment (temperature, humidity), temperature and pressure of steam exhaust of high-pressure cylinder, and incoming water temperature of deaerator. The output parameters are superheated, reheated steam (pressure, flow, temperature) and flue gas (temperature, oxygen, flow, and pressure). The testing parameters of internal system include drum water level, negative pressure of furnace, metal wall temperature of reheater, primary air pressure, powder position of silo, grinding pressure difference, outlet temperature of coal mill.

Level 2: The classification of complex large systems is mainly to improve the diagnostic speed. The actual system with the same configuration can obtain different subsystems and connection relationships due to different decomposition methods. There is no strict requirement for decomposition methods, but generally follows the following principles:

A. Divided by system functions, the subsystems can complete some independent physical functions;

B. The correlation between the input and output of the decomposed subsystem should be quite clear, which is conducive to the establishment of the qualitative equation of the subsystem;

C. The input and output of the subsystem are measurable parameters, so that the fault can be timely identified to a subsystem or the possibility of failure of a subsystem can be eliminated during the diagnosis;

D. The connection relationship between subsystems should be as simple as possible to reduce unnecessary solution paths;

E. Several units that may be involved in an influencing factor are grouped into a subsystem; 
In accordance with the above principles, the boiler system is divided into over-heating system, reheater system, furnace combustion system, air supply system, powder making system, water supply system, desuperheating system, drum and tail heating surface system.

In addition, several parameter adjustment systems are included to determine the connection relationship among subsystems according to various working medium and information flow. Each subsystem is described by an object. The input and output of the parameterized system in this level involve two independent subsystems, so it appears as a separate object in this level. Then the next level decomposition, or the third level decomposition, can be carried out for each subsystem. In this step-by-step decomposition, an object corresponds to a component or component in the last level decomposition.

\subsection{Energy efficiency index system of boiler system}

The energy efficiency index system of boiler system mainly includes thermal efficiency, exhaust temperature, excess air coefficient, slag carbon content and furnace surface temperature. Referring to the relevant standards,

Table 3: Targets and limits of the lowest thermal efficiency in the smoke exhaust temperature standards of the boiler system can be obtained as shown in Table 1.

Table 1: Standard of exhaust temperature of boiler system

\begin{tabular}{|c|c|c|}
\hline \multicolumn{2}{|c|}{$\begin{array}{c}\text { Rated evaporation }(\mathrm{t} / \mathrm{h}) / \text { Rated power } \\
(\mathrm{MW})\end{array}$} & $\begin{array}{c}\text { Exhaust } \\
\text { temperature }\left({ }^{\circ} \mathrm{C}\right)\end{array}$ \\
\hline \multirow{2}{*}{ Steam boiler } & $<1 \mathrm{t} / \mathrm{h}$ & $\leq 230$ \\
\cline { 2 - 3 } & $>1 \mathrm{t} / \mathrm{h}$ & $\leq 170$ \\
\hline \multirow{2}{*}{ Water boiler } & $<0.7 \mathrm{MW}$ & $\leq 180$ \\
\cline { 2 - 3 } & $>0.7 \mathrm{MW}$ & $\leq 170$ \\
\hline \multirow{2}{*}{$\begin{array}{l}\text { Organic heat } \\
\text { carrier boiler }\end{array}$} & $<1.4 \mathrm{MW}$ & $\begin{array}{c}\leq \text { Inlet medium } \\
\text { temperature } 50\end{array}$ \\
\cline { 2 - 3 } & $>1.4 \mathrm{MW}$ & $\leq 170$ \\
\hline
\end{tabular}

The index of air excess coefficient is shown in Table 2 . Table 2: Indicators of air excess coefficient

\begin{tabular}{|c|c|c|c|c|}
\hline $\begin{array}{c}\text { Boiler } \\
\text { type }\end{array}$ & $\begin{array}{c}\text { Fluidized } \\
\text { bed } \\
\text { boiler }\end{array}$ & $\begin{array}{c}\text { Layer- } \\
\text { burning } \\
\text { boiler }\end{array}$ & $\begin{array}{c}\text { Positive } \\
\text { pressure } \\
\text { fuel oil } \\
\text { (gas) } \\
\text { boiler }\end{array}$ & $\begin{array}{c}\text { Negative } \\
\text { pressure } \\
\text { fuel oil } \\
\text { (gas) } \\
\text { boiler }\end{array}$ \\
\hline $\begin{array}{c}\text { Excess } \\
\text { Coefficie } \\
\text { nt }\end{array}$ & $\leq 1.4$ & $\leq 1.65$ & $\leq 1.15$ & $\leq 1.25$ \\
\hline
\end{tabular}

Relevant standards of boiler thermal efficiency are shown in Table 3:

\begin{tabular}{|c|c|c|c|c|c|c|c|c|c|c|c|c|}
\hline \multirow{4}{*}{ Fuel typ } & & \multirow{4}{*}{$\begin{array}{l}\text { Qnet,v,ar } \\
(\mathrm{KJ} / \mathrm{kg})\end{array}$} & \multicolumn{10}{|c|}{ Rated evaporation $(\mathrm{D}, \mathrm{t} / \mathrm{h})$ or Rated power(Q,MW) } \\
\hline & & & \multicolumn{2}{|c|}{$\begin{array}{c}\mathrm{D}<1 \\
\text { Or } \mathrm{Q}<0.7\end{array}$} & \multicolumn{2}{|c|}{$\begin{array}{c}1 \leq \mathrm{D} \leq 2 \\
\text { Or } 0.7 \leq \mathrm{Q} \leq 1.4\end{array}$} & \multicolumn{2}{|c|}{$\begin{array}{c}2<\mathrm{D} \leq 8 \text { Or } 1.4 \\
<\mathrm{Q} \leq 5.6\end{array}$} & \multicolumn{2}{|c|}{$\begin{array}{c}8<\mathrm{D} \leq 20 \\
\text { Or } 5.6<\mathrm{Q} \leq 14\end{array}$} & \multicolumn{2}{|c|}{$\begin{array}{c}\mathrm{D}>20 \\
\text { Or } \mathrm{Q}>14\end{array}$} \\
\hline & & & \multicolumn{10}{|c|}{ Boiler thermal efficiency $(\%)$} \\
\hline & & & $\begin{array}{l}\text { Target } \\
\text { value }\end{array}$ & $\begin{array}{l}\text { limit } \\
\text { value }\end{array}$ & $\begin{array}{l}\text { Target } \\
\text { value }\end{array}$ & $\begin{array}{l}\text { limit } \\
\text { value }\end{array}$ & $\begin{array}{l}\text { Target } \\
\text { value }\end{array}$ & $\begin{array}{l}\text { limit } \\
\text { value }\end{array}$ & $\begin{array}{l}\text { Target } \\
\text { value }\end{array}$ & $\begin{array}{l}\text { limit } \\
\text { value }\end{array}$ & $\begin{array}{l}\text { Target } \\
\text { value }\end{array}$ & $\begin{array}{l}\text { limit } \\
\text { value }\end{array}$ \\
\hline \multirow{2}{*}{$\begin{array}{l}\text { Bituminous } \\
\text { coal }\end{array}$} & II & $\begin{array}{l}17700- \\
21000\end{array}$ & 74 & 69 & 77 & 72 & 79 & 74 & 80 & 75 & 81 & 76 \\
\hline & III & $>21000$ & 76 & 74 & 79 & 74 & 81 & 76 & 82 & 77 & 83 & 78 \\
\hline $\begin{array}{c}\text { Meagre } \\
\text { coal }\end{array}$ & & $\geq 17700$ & 72 & 67 & 75 & 70 & 77 & 72 & 79 & 74 & 80 & 75 \\
\hline \multirow{2}{*}{$\begin{array}{c}\text { Anthracite } \\
\text { coal }\end{array}$} & II & $\geq 21000$ & 61 & 56 & 64 & 59 & 67 & 62 & 69 & 64 & 72 & 67 \\
\hline & III & $\geq 21000$ & 66 & 61 & 71 & 66 & 75 & 70 & 77 & 72 & 80 & 75 \\
\hline $\begin{array}{l}\text { Lignitous } \\
\text { coal }\end{array}$ & & $\geq 11500$ & 72 & 67 & 75 & 70 & 77 & 72 & 79 & 74 & 81 & 76 \\
\hline
\end{tabular}




\section{Evaluation model and method of energy consumption factors of boiler system}

\subsection{Analytic Hierarchy Process}

Analytic Hierarchy Process (AHP) is first proposed by Saaty, a professor at the university of Pittsburgh, in the 1970s. This method is a simple method that combines qualitative and quantitative means to make decision for complex or fuzzy decision evaluation problems. In particular, it quantifies the actual experience judgment of experts, scientifically levels the thinking process of human beings, compares relevant factors layer by layer, and scientifically tests the rationality of the results. Therefore, this method has strong persuasive power[8].

When using AHP method to determine the weight of each level of indicators, it generally divided into four steps: 1) establish a hierarchical structure model; 2) construct paired comparison judgment matrix; 3) single ranking and consistency test of the judgment matrix; 4) obtain the comprehensive weight vector.

\subsection{Evaluation index weight calculation}

Because of the dispersion of indicators and the different effects of the results, it is difficult to draw a comprehensive, objective and comprehensive conclusion when traditional evaluation indicators and methods are adopted. Constructing a comprehensive evaluation model to analyze the weight of each influencing factor is necessary.

The key to establish the evaluation model is to analyze the factors affecting the energy consumption of the boiler system and rank them. The main influencing factors of boiler system are as follows: exhaust temperature, excess air coefficient, cold air temperature, fuel volatilization, carbon content of slag, boiler capacity, slag temperature. The main factors considered at the criterion level include: Exhaust heat loss q2, Incomplete combustion heat loss of combustible gas q3, Heat loss from incomplete combustion of solids q4, Boiler heat loss q5, Ash physical sensible heat loss q6. The evaluation model of influencing factors of boiler energy consumption is shown in Table 4 .

Table 4 Evaluation model for influencing factors of boiler

\begin{tabular}{|c|c|c|}
\hline \multicolumn{3}{|c}{ energy consumption } \\
\hline Target layer & Criterion layer & Index layer \\
\cline { 2 - 3 } & Exhaust heat loss q2 & $\begin{array}{c}\text { Exhaust } \\
\text { temperature }\end{array}$ \\
\cline { 2 - 3 } $\begin{array}{c}\text { Ranking of } \\
\text { boiler system } \\
\text { efficiency } \\
\text { influencing } \\
\text { factors }\end{array}$ & \begin{tabular}{c} 
Incomplete \\
of combustion heat loss \\
\cline { 2 - 3 }
\end{tabular} & $\begin{array}{c}\text { Heat loss from } \\
\text { incomplete } \\
\text { parameter }\end{array}$ \\
\cline { 2 - 3 } & $\begin{array}{c}\text { combustion of solids } \\
\text { q4 }\end{array}$ & $\begin{array}{c}\text { Cold air } \\
\text { temperature }\end{array}$ \\
\cline { 2 - 3 } & Boiler heat loss q5 & $\begin{array}{c}\text { Carbon content of } \\
\text { slag }\end{array}$ \\
\cline { 2 - 3 } & Capacity of boiler \\
\hline
\end{tabular}

\begin{tabular}{|c|c|c|}
\hline & $\begin{array}{c}\text { Ash physical } \\
\text { sensible heat loss q6 }\end{array}$ & Slag temperature \\
\hline
\end{tabular}

The consistency verification results of the indicator judgment matrix are shown in Table 5.

The weight of the ranking of influencing factors of boiler system efficiency is shown in Table 6 .

Table 5 Consistency check results of judgment matrix

\begin{tabular}{|c|c|c|c|}
\hline Check index & CI & RI & CR \\
\hline Criterion layer & 0.026 & 1.13 & 0.023 \\
\hline Exhaust heat loss & 0.001 & 1.00 & 0.001 \\
\hline $\begin{array}{c}\text { Incomplete combustion heat } \\
\text { loss of combustible gas }\end{array}$ & 0.06 & 1.20 & 0.05 \\
\hline $\begin{array}{c}\text { Heat loss from incomplete } \\
\text { combustion of solids }\end{array}$ & 0.07 & 1.40 & 0.05 \\
\hline Boiler heat loss & 0.09 & 1.29 & 0.07 \\
\hline Ash physical sensible heat loss & 0.01 & 1.00 & 0.01 \\
\hline
\end{tabular}

Table 6 Calculation results of weight factors influencing efficiency of boiler system

\begin{tabular}{|c|c|c|c|}
\hline $\begin{array}{l}\text { Target } \\
\text { layer }\end{array}$ & Criterion layer & Index layer & $\begin{array}{l}\text { Index } \\
\text { weight }\end{array}$ \\
\hline \multirow{7}{*}{$\begin{array}{l}\text { Ranking of } \\
\text { boiler } \\
\text { system } \\
\text { efficiency } \\
\text { influencing } \\
\text { factors }\end{array}$} & $\begin{array}{c}\text { Exhaust heat loss } \\
\text { q2(0.5509) }\end{array}$ & $\begin{array}{c}\text { Exhaust } \\
\text { temperature }\end{array}$ & 0.3361 \\
\hline & \multirow{2}{*}{$\begin{array}{c}\text { Incomplete } \\
\text { combustion heat } \\
\text { loss of combustible } \\
\text { gas q3(0.0767) }\end{array}$} & $\begin{array}{l}\text { Excess air } \\
\text { parameter }\end{array}$ & 0.1465 \\
\hline & & $\begin{array}{c}\text { Cold air } \\
\text { temperature }\end{array}$ & 0.0909 \\
\hline & $\begin{array}{l}\text { Heat loss from } \\
\text { incomplete } \\
\text { combustion of } \\
\text { solids q4 }(0.1891) \\
\end{array}$ & $\begin{array}{c}\text { Fuel } \\
\text { volatilization }\end{array}$ & 0.1681 \\
\hline & \multirow{2}{*}{$\begin{array}{l}\text { Boiler heat loss } \\
\text { q5(0.1225) }\end{array}$} & $\begin{array}{l}\text { Carbon } \\
\text { content of } \\
\text { slag }\end{array}$ & 0.0865 \\
\hline & & $\begin{array}{c}\text { Capacity of } \\
\text { boiler }\end{array}$ & 0.1120 \\
\hline & $\begin{array}{c}\text { Ash physical } \\
\text { sensible heat loss } \\
q 6(0.0608)\end{array}$ & $\begin{array}{c}\text { Slag } \\
\text { temperature }\end{array}$ & 0.0599 \\
\hline
\end{tabular}

Through the AHP evaluation model and calculation, the weights of the 7 influencing factors exhaust temperature, excess air coefficient, cold air temperature, fuel volatilization, carbon content of slag, boiler capacity, slag temperature are respectively $33.6 \%, 14.7 \%, 9.1 \%$, $16.8 \%, 8.7 \%, 11.2 \%, 6.0 \%$. That is, the boiler energy consumption factors from large to small in order for exhaust temperature, fuel volatilization, excess air coefficient, boiler capacity, cold air temperature, carbon content of slag, slag temperature.

The above influencing factors lay a foundation for the diagnosis of boiler energy consumption and energy saving. In the process of boiler energy consumption diagnosis, the boiler energy consumption can be diagnosed in accordance with the above sequence, and the performance index calculation and benchmarking can be carried out according to the diagnostic test data.

\section{Conclusions}

This paper mainly studies the energy saving diagnosis 
method and evaluation model of boiler system, determines 7 factors that affect the energy consumption of boiler, and calculates the weight of the influencing factors by AHP. The indexes selected have certain representativeness and the evaluation effect is more comprehensive. The index system established in this paper can provide direction for energy saving diagnosis of boiler system and has certain theoretical and practical significance.

\section{References}

1. LI N, TIAN WJ, HE T, ZHANG ZF, BAI H, CANG DQ. (2020) Energy Saving Diagnosis Model of Industrial Boiler Based on Dynamic Data Simulation. J . Industrial Furnace.,42(01):1-8.

2. LI LH. (2020) Analysis on the problems in the energy efficiency test of industrial boilers and the potential of energy saving. $J$. ENERGY CONSERVATION.,39(01):165-166.

3. ZHANG HR. (2019) Study on energy efficiency test and energy saving diagnosis of industrial boiler. J . China Plant Engineering.,2019(21):110-112.

4. WANG XY. (2018) Study on Energy Efficiency Monitoring and Analysis Technology of Industrial Boiler. J . Intelligent Building.,2018(08):49-54.

5. WANG X.(2016) Technical innovation research on energy saving and efficiency improvement of industrial pulverized coal boiler. J. Clean Coal Technology.,22(01):82-85.

6. ZHANG J, LI XY, HE YH, YU F. (2015) Analysis of Energy Saving Problems of Industrial Boilers. J .Journal Of Engineering For Thermal Energy And Power.,35(04):280-287.

7. Li LY. (2019) Discussion on Application Strategies of Energy Saving and Consumption Reduction Technology in Power Plant Boiler Operation. J . Engineering Technology and Application.,4(22):102-103.

8. YANG L, REN J.(2019) Low Carbon Comprehensive Evaluation of Coal-Fired Power Plants Based on Analytic Hierarchy Process. J . Power Generation Technology.,40(01):66-70. 